\title{
指向性GPSアンテナの放射特性解析
}

\author{
宮野 智行*·石島 義之*・安田 明生**

\section{Radiation Pattern Analysis of a GPS Directional Antenna} \\ Tomoyuki MIYANO, Yoshiyuki ISHIJIMA and Akio YASUDA
}

\begin{abstract}
This paper presents the results of the investigation for the receiving antennas with directional gain in order to receive the GPS signals in the geostationary orbit. For the use GPS in geostationary orbit the receiver has to process signals that come from the other side of the earth. It is desired to receive two frequency of GPS signals ( $\mathrm{L} 1: 1575.42 \mathrm{MHz} / \mathrm{L} 2: 1227.6 \mathrm{MHz}$ ) in order to correct the Ionospheric delay. The radiation analysis is performed in order to examine the gain pattern and the directional characteristics of the helical antenna. The computed gains at L1 and L2 of the helix antenna is +15.9 $\mathrm{dBi}$ and $+13.6 \mathrm{dBi}$ respectively with beamwidth of 25 degrees after this analysis. The computed voltage standing wave ratio (VSWR), gain pattern and axial ratio characteristics agreed well with the measured data of the prototype quadrifilar helical antenna.
\end{abstract}

Key words : satellite navigation, GPS, antenna, geostationary satellite キーワード：衛星航法, GPS, アンテナ, 静止衛星

\section{1. はじめに}

近年GPSは民生分野における利用が拡大してお り、時刻基準や精密位置情報などの社会基盤となる 情報サービスが提供されるようになってきている。 宇宙分野においてもGPSは中低軌道衛星や宇宙往 還機の航法機器として広く利用されている。これま でGPSの地上利用では無指向性のアンテナが使用 されてきたが、スードライト地上局の送信アンテナ やGPS大気観測等では、高利得の指向性GPSアンテ 十の開発が望まれている。宇宙利用においても宇宙 機の姿勢変化に対応できるように無指向性のアンテ ナが使用されてきたが、静止軌道や準天頂軌道にお けるGPS利用では、指向性GPSアンテナを使用する ことが望ましい。これは静止軌道上では地球を挟ん で高度 $20,000 \mathrm{~km}$ に位置するGPS衛星から送信され た信号を受信することになるが (Fig. 1)、高利得ア ンテナを使用すれば一般のGPS受信機が受信して いるGPS衛星送信アンテナのメインローブ信号だ
けでなく、サイドローブ信号も受信することができ るようになり、測位に必要な観測データが増加する ためである。この時、伝搬経路上に存在する電離層 によって生じる遲延誤差を補正するために、GPS信 号の 2 周波数 (L1、L2) を受信することが必要とな る。アンテナの形式としては、衛星搭載性を考慮し て高利得 ( $+10 \mathrm{~dB}$ 以上) を得るためには、ヘリカル アンテナが適している。静止衛星以外のミッション では、低軌道衛星において電離層密度や大気の可降 水量を観測するミッションや測位衛星の送信アンテ 十等でも、衛星搭載用の 2 周波GPSアンテナが必要 となる。本論文では、静止衛星搭載用に適した特性 を得るために、モーメント法による解析を行って、 巻き数、リム高、ピッ千角の 3 つのパラメータにつ いて最適化を行った。そして得られたパラメータを 用いてへリカルアンテナを製作し、指向性や利得を 測定した結果、解析と同等の特性が得られ、解析の 有効性が確認できた。これによって静止軌道におい ても測位に必要なGPSの観測データ数が確保でき、

* 正会員 宇宙開発事業団（干305-8505＼cjkstart茨城県つくば市千現2-1-1）

**正会員 東京商船大学（广135-8533 東京都江東区越中島2-1-6) 
連続して高精度な時刻、位置、速度情報を提供する ことが可能となると考える。

\section{2. 要求仕様の検討}

本稿では、静止軌道でGPS信号の受信が可能とな るような指向性が強く利得の高い受信アンテナの放 射特性解析を行う。静止軌道では地球を挟んで高度 $20,000 \mathrm{~km}$ に位置するGPS衛星から送信された信号 を受信するため、受信できる搬送波対雑音比 $\left(\mathrm{CN}_{0}\right)$ が20〜 45 dBHz と地上のGPS受信機のC/ $\mathrm{N}_{0}(35 \sim 50$ $\mathrm{dBHz}$ )より低くなる。GPS衛星の送信アンテナのサ イドローブ信号まで受信するためには、 $20 \mathrm{dBHz}$ 〜25 dBHzの信号を処理する必要がある。GPS衛星 送信アンテナのゲインパターンをFig. 2に示す(1)。 このレベルの受信を受信機の改良だけで達成するこ とは難しい。一方、静止衛星から見たGPS衛星の視 線方向ベクトルは、両衛星の軌道高度 (GPS衛星： $20,000 \mathrm{~km}$ 、静止衛星：36,000 km) 加幾何学的に 定まる。GPS衛星の送信アンテナのメインローブを $21^{\circ}$ 以内とすると、静止衛星の受信アンテナは地球方 向から $12.6^{\circ}$ 以内まで利得が必要となる(Fig. 1)。送 信アンテナのサイドローブを $36^{\circ}$ 以内とすると、静止 衛星の受信アンテナの放射ビームは $23^{\circ}$ 以内である ことが必要となる。このような条件から静止衛星搭 載用GPSアンテナに求められる仕様を、ビ一ム幅 $25^{\circ}$ 以上、利得は+12 $\mathrm{dBi}$ 以上とした。その他の要求とし ては、周波数はL1、L2の 2 波を受信し、それぞれの 帯域でVSWRを1.5以下とする。衛星搭載を前提と しているため、高さ方向は許容されるが、底面積は 小さくする必要がある。マルチパスの影響を避ける ためサイドローブレベルを低く抑える必要があるな どが挙げられる。以上に述べた静止衛星搭載用GPS アンテナに対する要求仕様をTable 1にまとめる。

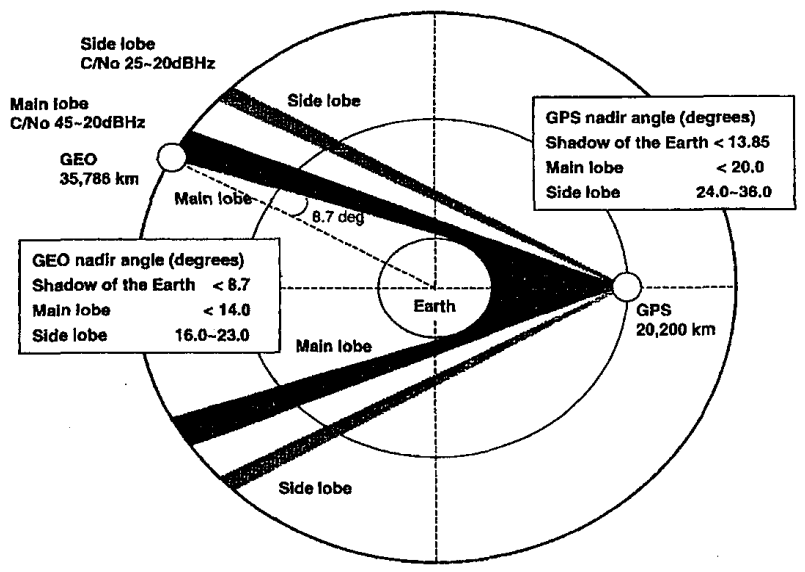

Fig. 1. Geometry of GPS satellite and geo-synchronous satellite
GPS antenna gain pattern

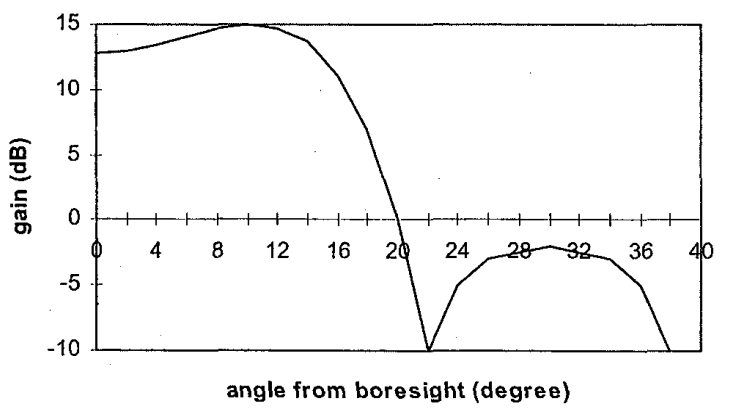

Fig. 2. Antenna gain pattern of GPS satellite

Table 1. Requirement specifications for the GPS antenna in the geostationary orbit

\begin{tabular}{ll}
\hline Items & Requirement values \\
\hline Frequency & L1:1575.42MHz \\
& L2:1227.6MHz \\
Impedance & $50 \Omega$ \\
Gain & $>12 \mathrm{dBi}$ \\
Dimension & $<\phi 200 \mathrm{~mm}$ \\
VSWR & $<1.5$ \\
Beam width & $>25^{\circ}$ \\
Side-lobe level & $<-10 \mathrm{~dB}$ \\
F/B & $>20 \mathrm{~dB}$ \\
Circular polarization & Right handed circular polarization \\
\hline
\end{tabular}

\section{3. 放射特性解析}

\section{1 基礎検討}

ヘリカルアンテナの特性解析をモーメント法を用 いて行い、パラメータの最適化を行った。へリカル アンテナは、その円周 $\mathrm{C}_{\lambda}$ がほぼ 1 波長、ピッチ角 $\alpha$ $12^{\circ} \sim 14^{\circ}$ の時、アンテナの軸方向に鋭い指向性を有 する。この放射モ一ドは軸モ一ドと呼ばれ実験的、 理論的に検討されてきた ${ }^{(2)(3)}$ 。基本的な特性として は、巻き数 $\mathrm{N}$ 多くするほど利得は高くなり、軸比も 良くなることが確認されている。また、軸モ一ドへ リカルアンテナは有限の反射板を有し、この反射板 の大きさにより利得、軸比が変化することが報告さ れている(4)。アンテナの各パラメータについては以 下のことが述べられている。

(1) 反射板の大きさが1.6波長程度の時、利得が最 大となる。

(2) ピッチ角は $12^{\circ} の$ 時の方が $14^{\circ} の$ 時よりも利得 が高くなる。

（3）軸比はピッチ角が $14^{\circ} の$ 時の方が $122^{\circ}$ の時より も良い。(巻き数が10回転より少ない場合顕著で ある。) 


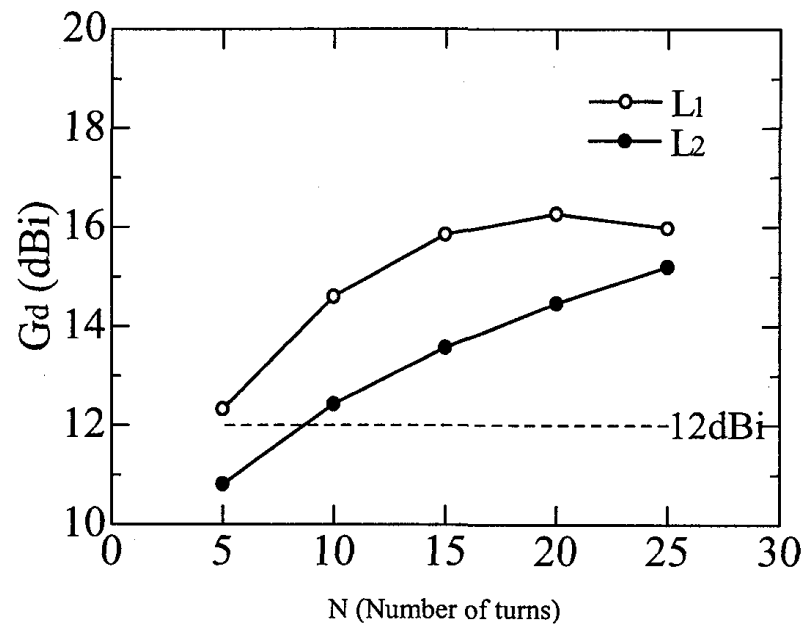

Fig. 3(a). Number of helical turns and directional gain

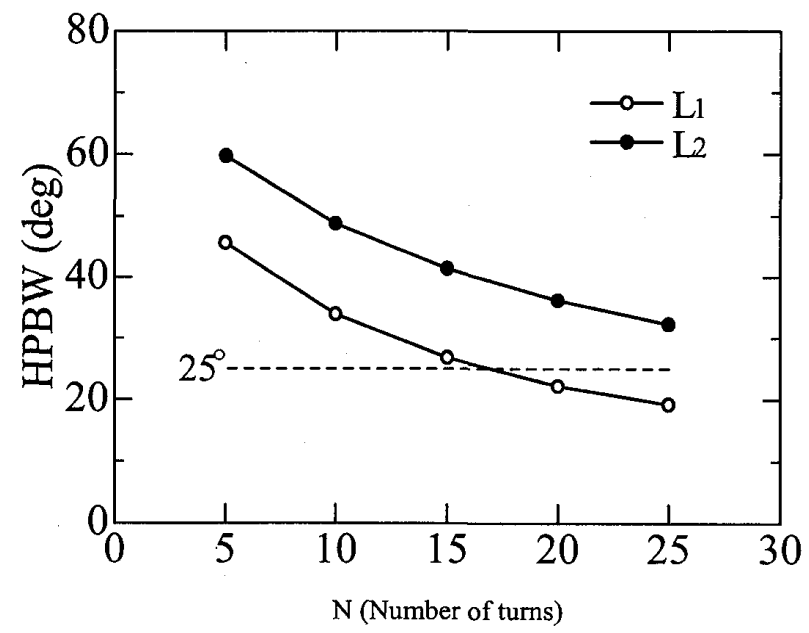

Fig. 3(b). Number of helical turns and beam width

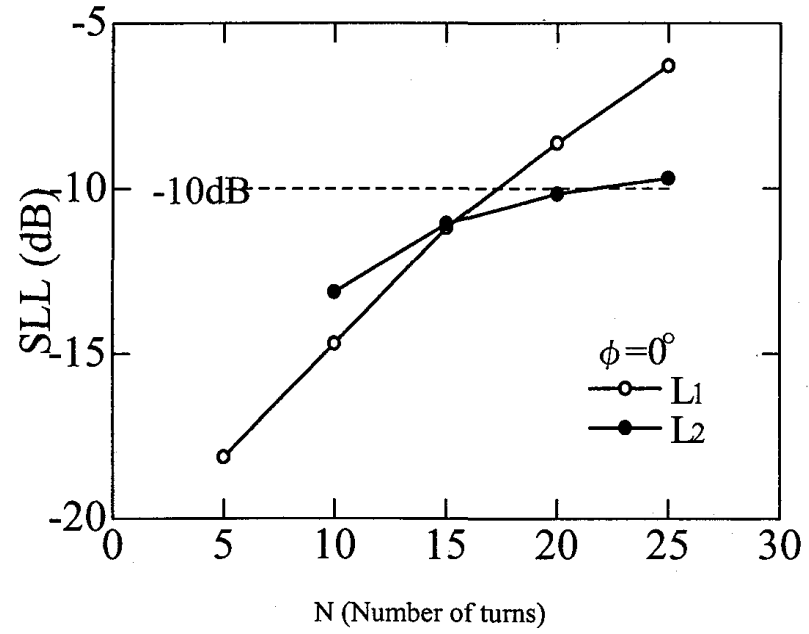

Fig. 3(c). Number of helical turns and sidelobe level

本検討においては、L1とL2の両周波数を満足させる 必要があるので、周波数をその中心の周波数 $\mathrm{fc}$

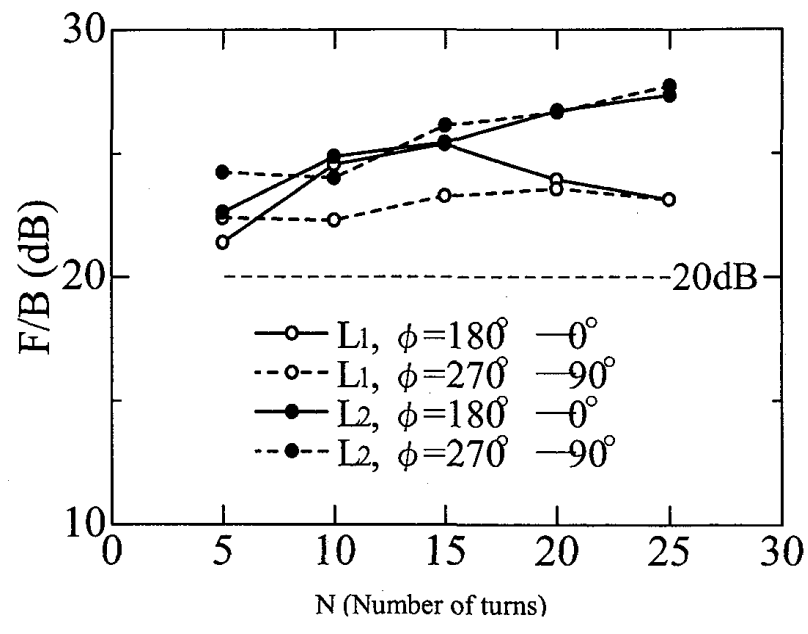

Fig. 3(d). Number of helical turns and F/B

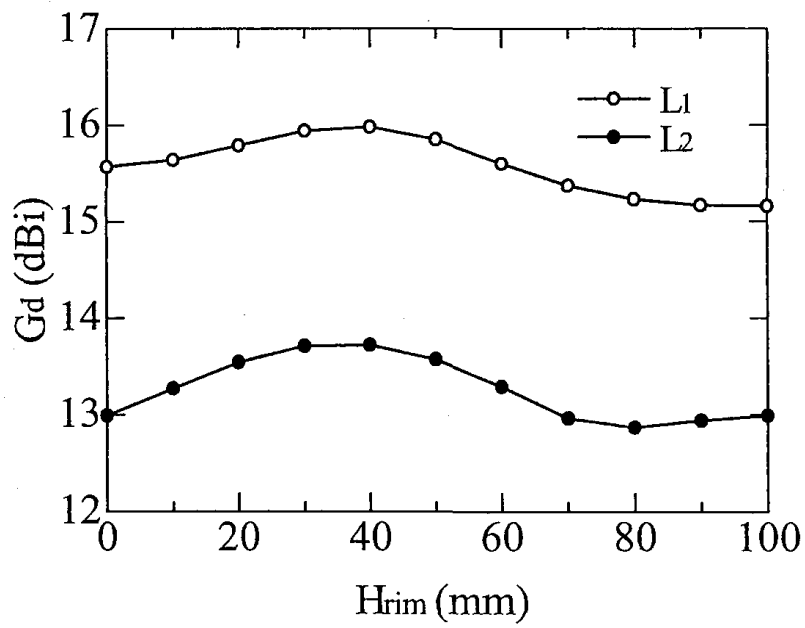

Fig. 4(a). Height of limb and directional gain

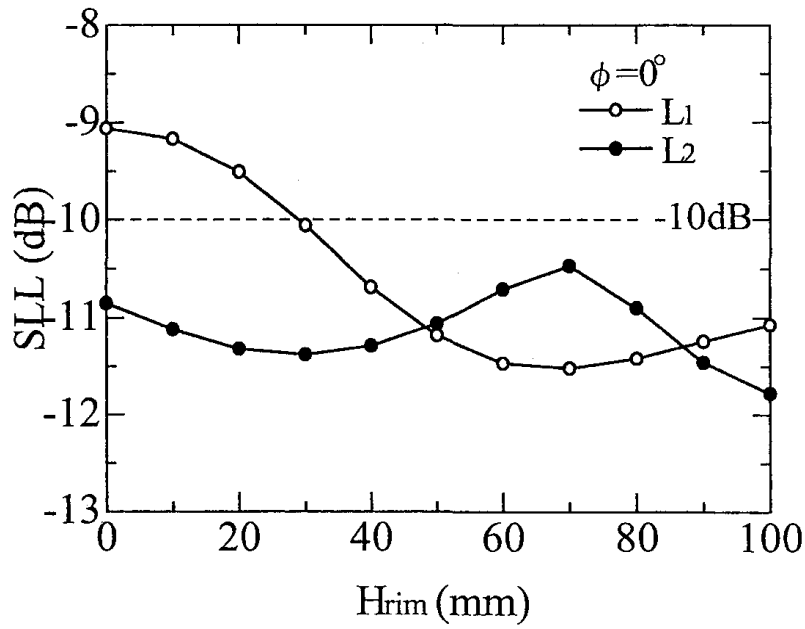

Fig. 4 (b). Height of limb and side-lobe level

（1401.51 MHz）（波長 $21.4 \mathrm{~cm} ）$ と仮定した。仮に （1）より、もし反射板の大きさを約1.6波長とすると、 


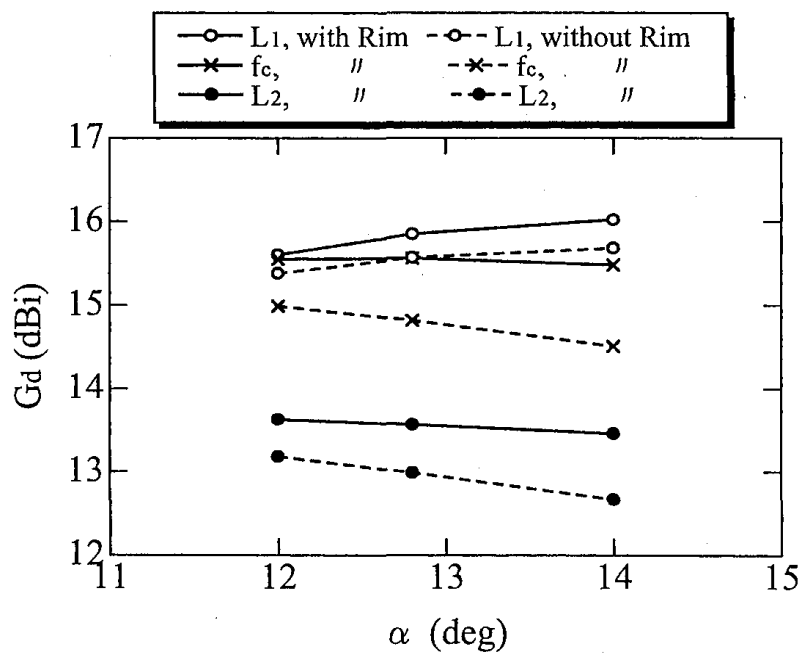

Fig. 5(a). Height of limb and directional gain

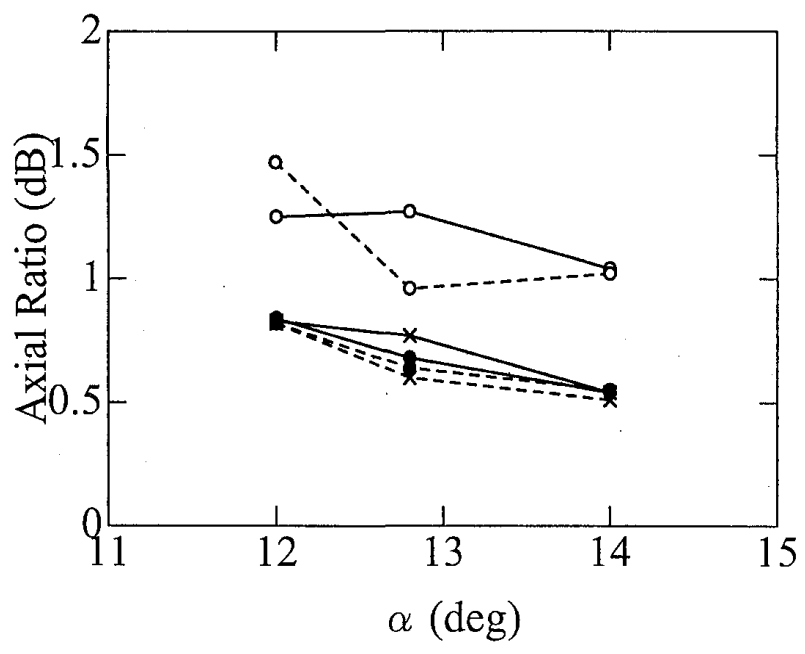

Fig. 5(b). Height of limb and axial ratio

約 $\phi 342 \mathrm{~mm}$ となり底面積が大きくなる。一方、反射 板を小さくするとバックローブが大きくなり、反軸 方向の放射に移行し、軸方向へ放射させるためには $\phi 0.5$ 波長より大きくする必要がある(5)。ここでは、 反射板を軸方向に折り返方構造にした場合について 検討する。底面積の制限より、反射板を $\phi 200 \mathrm{~mm}$ (約 1 波長)に固定した。リム高の初期設定值は約 $1 / 4$ 波 長となる50 mmとし、リム高を変化させた時の諸特 性の変化を解析検討により明らかにする。また、ピッ チ角については、上記 (2)、（3）より、初期設定値を $12.8^{\circ}$ とし、解析により再度検証する。一方、指向性 利得 $(\mathrm{Gd})$ は、次式で近似される(2)。

$$
\mathrm{Gd} \simeq 12 \mathrm{C}_{\lambda}{ }^{2} \mathrm{NS} \lambda \quad \text { (倍) }
$$

（ただし、 $0.8<\mathrm{C}_{\lambda}<1.15 、 12^{\circ}<\alpha<14^{\circ} 、 \mathrm{~N}>3$ ) $\mathrm{C}_{\lambda}$ : ヘリカル円周, $\mathrm{N}$ : 巻き数, $\mathrm{S}_{\lambda}$ : ピッチ

文献 (2)では実験値と比較しているが、この近似式
Table 2. Axial-mode helical antenna

(Pre-condition for the analysis)

\begin{tabular}{ll}
\hline Parameter & Design value \\
\hline Diameter of antenna & $\phi 70 \mathrm{~mm}(\fallingdotseq 0.33 \lambda /$ \\
& circumference $\left.\mathrm{C}_{\lambda} \fallingdotseq 1.03 \lambda\right)$ \\
Diameter of reflector & $\phi 200 \mathrm{~mm}(\fallingdotseq 0.93 \lambda)$ \\
Diameter of helical elements & $\phi 2 \mathrm{~mm}$ \\
\hline
\end{tabular}

は測定値と比べ高くなる傾向にある。精度も不十分 であり、反射板の大きさも考虑されていない。よっ て、初めにモーメント法による数值解析により所望 の利得を得るための巻き数を決定した。モーメント 法は、アンテナ素子を複数のセグメントに分けて、 自己、相互インピーダンスを求めてマトリックス化 し、その逆行列からアンテナ素子の荷電分布を求め る方法であり、アンテナの特性解析では一般的に利 用されている手法である。セグメントと基底関数を 適切に選択することにより、計算負荷を抑之て精度 の良い解析が行える。

\section{2 解析による検討}

Table 2に解析モデルの固定のパラメータを示す。 反射板はワイヤグリッド法によりモデル化した。

(1)巻き数

Fig. 3は、リム高 $50 \mathrm{~mm}$,ピッチ角 $12.8^{\circ}$ とし、巻き 数を変化させた時の諸特性を示す。Fig. 3(a)に軸方 向 $\left(\theta=0^{\circ}\right)$ の指向性利得を示す。この結果、L1の周波 数では巻き数が20回転の時に最大となり、20回転以 上では利得向上の効果は小さくなる。これはFig. 3(c)からもわかるように、巻き数を多くとることに よりサイドローブレベルも高くなり、特にL1の周波 数においてこの傾向が顕著に現れるからである。な

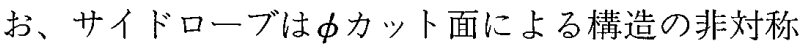
性によりバラツキを生じ、 $\phi=0^{\circ} 、 90^{\circ} 、 180^{\circ} 、 270^{\circ}$ を 計算した結果、 $\phi=0^{\circ}$ (給電位置方向)の時、サイド ローブレベルが最も高くなった。また、Fig. 3(b)よ ク、巻き数を多くすることにより、ビーム幅は鋭く なっていくが、 $25^{\circ}$ 以上を得るためには 15 回転以下に する必要がある。Fig. 3(d)に示すように、F/Bは巻 き数による変化はほとんど見られないが、 $20 \mathrm{~dB}$ 上を得ることができる。な扮 $\mathrm{F} / \mathrm{B} は \theta=180^{\circ} \pm 60^{\circ}$ の 範囲の最悪值で評価した。上記の結果と Table 1の条 件、導体損等の損失のマージンなどを考慮し、巻き 数を15回転に決定した。

(2)リムによる効果

巻き数を15回転、ピッチ角 $12.8^{\circ}$ に固定し、リム高 を0〜100 mmにした時の特性の変化について調べ た。Fig. 4 (a) は指向性利得を示し、リム高を $40 \mathrm{~mm}$ 
にした時、リム無し $\left(\mathrm{H}_{\mathrm{rim}}=0 \mathrm{~mm}\right)$ に比べ、L1で0.4 $\mathrm{dB} 、 \mathrm{~L} 2 て ゙ 0.7 \mathrm{~dB}$ 利得が向上した。また、サイドロー ブは $\phi=0^{\circ}$ (給電位置方向) で最悪値をとり、その変 化をFig. 4(b)に示す。四よりリム高をそれぞれL1 で70 mm、L2で30 mmとした時、最もサイドローブ 抑圧効果が現れる $\left(\phi=90^{\circ} 、 180^{\circ} 、 270^{\circ}\right.$ でもサイド ローブの抑圧の効果は得られるがその最適值はそれ ぞれ違うことから、これらの中の最徳值を示す $\phi=$ 0にて評価した)。リム高を50 mmにした時にL1、L2 の両周波数における最適值となる。以上の結果より、 リ 厶高は初期設定值の50 mmが適当であると考えら れる。

(3)ピッチ角

巻き数 15 回転としてピッチ角による諸特性の変化 について調べた。Fig. 5(a)にピッチ角による軸方向 指向性利得の変化を示す。3.1の(2)で述べたピッチ 角と利得の関係は、へリカルの周長が 1 波長の時に は成り立つが、周波数を高く（周長を 1 波長よりも 長く）した時は、逆にピッチ角を大きくした方が、 指向性利得を向上させる。また、(高さ50 mm) リム の有無によってもその変動幅は変化する。周波数に よる利得差を小さくする場合、ピッチ角を小さくし た方が有利である。Fig. 5(b)にピッチ角によるボ

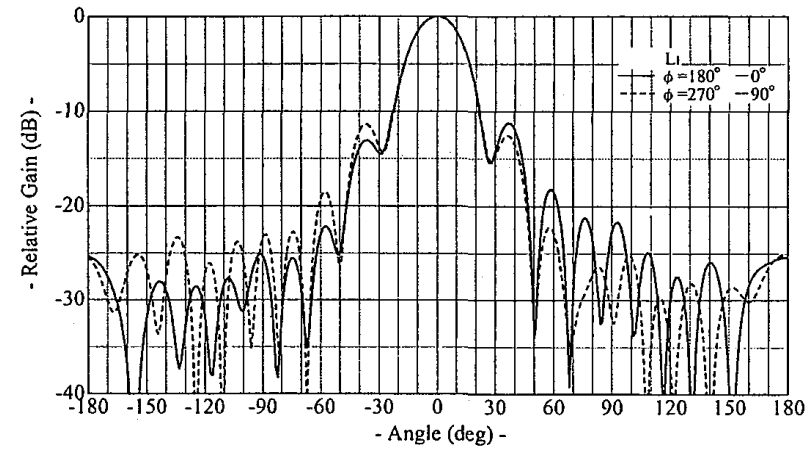

Fig. 6(a). Right handed circular polarization L1 (Analytical value)

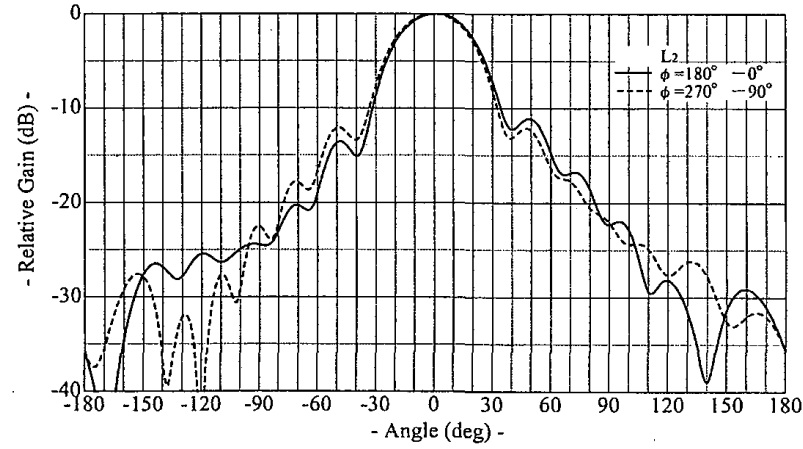

Fig. 6(b). Right handed circular polarization L2 (Analytical value)

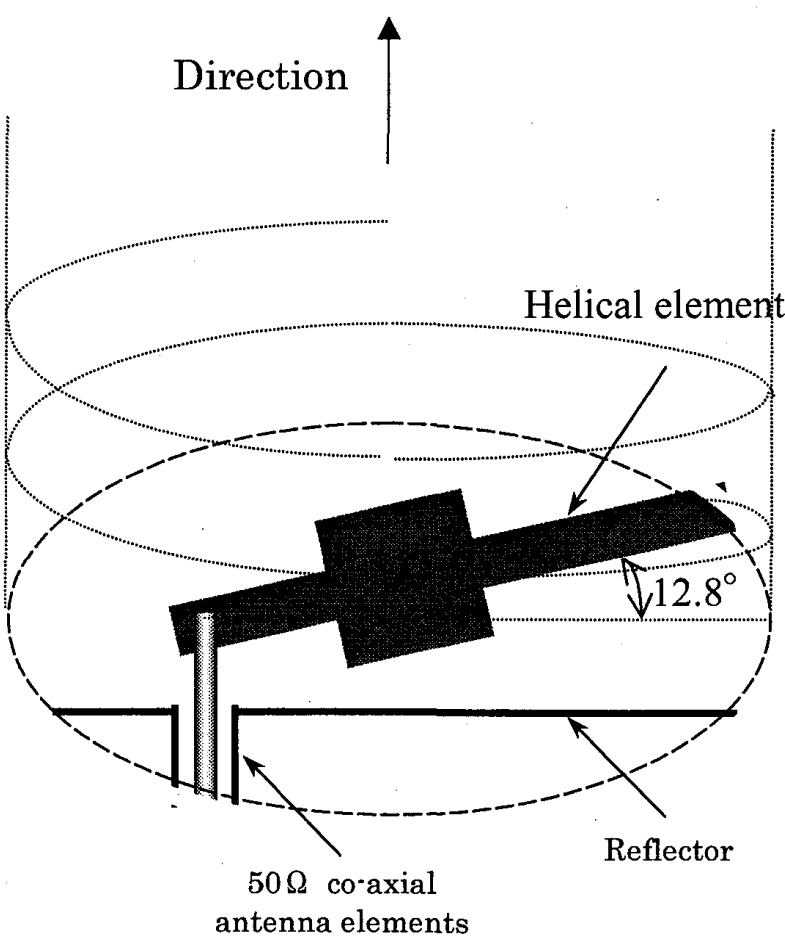

Fig. 7. Adjustment of the prototype antenna gain

Table 3. Side-lobe level

\begin{tabular}{ccc}
\hline$\phi$ & $\mathrm{L1}$ & $\mathrm{L} 2$ \\
\hline $0^{\circ}$ & -11.2 & -11.1 \\
$90^{\circ}$ & -12.5 & -12.1 \\
$180^{\circ}$ & -13.0 & -13.5 \\
$270^{\circ}$ & -11.4 & -12.0 \\
\hline
\end{tabular}

アサイト万向の軸比の変化を示す。3.1の(3)で述べ たピッチ角と軸比の関係は（高さ50 mm）リムの有 無に関わらずほぼ成り立ち、巻き数が15回転と多い ためピッチ角による影響は小さいことも確認でき た。また軸比を考えた場合、ピッチ角を大きくする ことにより、僅かながら改善することができる。軸 方向の指向性利得と軸比を検討した結果、ピッチ角 $12.8^{\circ}$ が適当であると考えられる。

(4)解析結果のまとめ

解析の結果、巻き数、リム高、ピッ千角をそれぞ れ、15回転、50 mm、12.8 に決定する。この時、L2 で13.6 dBi（L1で15.9 dBi）の指向性利得が得られ た。Fig. 6に巻き数15回転の時の右旋円偏波指向性 を示す。この時、ビーム幅は $\phi=0^{\circ} 、 90^{\circ}$ ともに $27^{\circ}$ (L1) $/ 41^{\circ}(\mathrm{L} 2)$ となり、カット面によるサイドローブ レベルをTable 3に示す。この結果、カット面による 分散は僅かである。またボアサイト方向の軸比は $0.7 \mathrm{~dB}(\mathrm{~L} 1) / 1.3 \mathrm{~dB}(\mathrm{~L} 2)$ であった。 


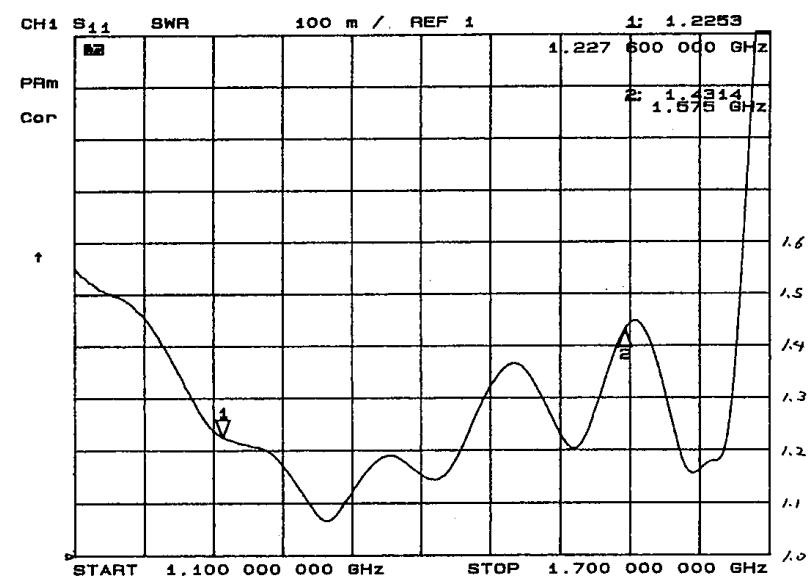

Fig. 8. Voltage Standing Wave Ratio of the prototype antenna (VSWR)

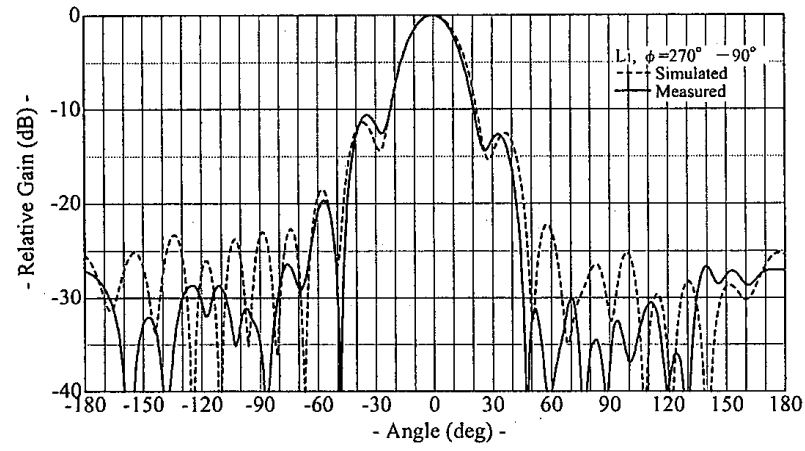

Fig. 9(a). Characteristic of right handed circular polarization (L1)

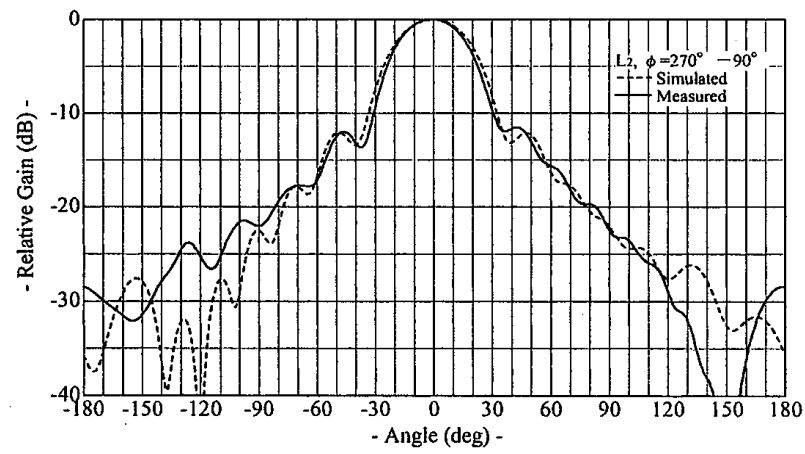

Fig. 9(b) . Characteristic of right handed circular polarization (L2)

\section{4. 放射特性の測定と評価}

\section{1 入カインピーダンス}

円周上で給電される軸モードヘリカルアンテナの 入力インピーダンスは近似的に下式で与えられ $ろ^{(2)}$ 。

$$
Z_{\text {in }}=150 / \sqrt{C \lambda} \quad[\Omega]
$$

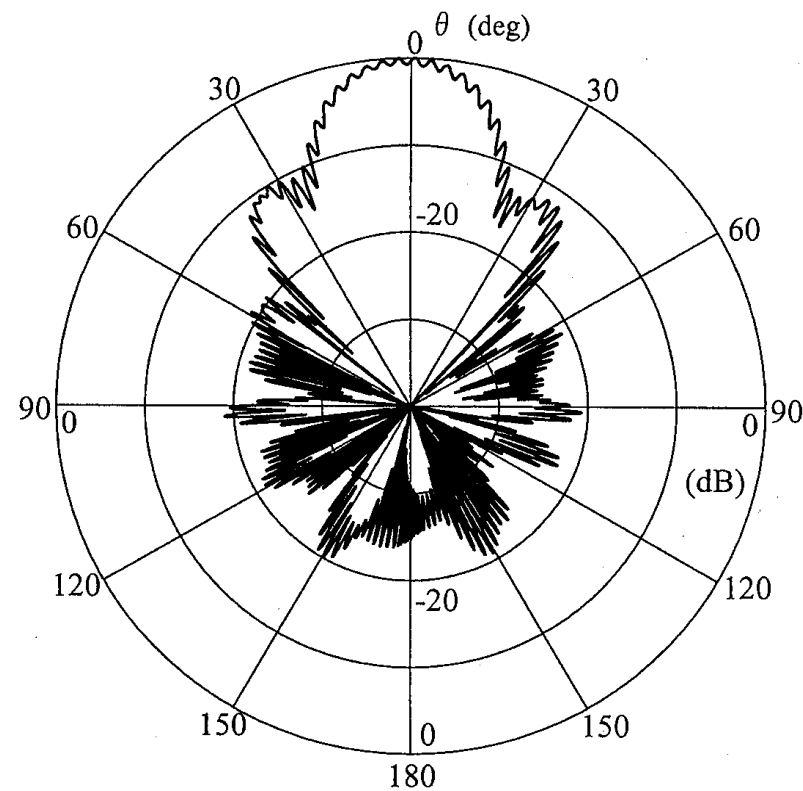

Fig. 10(a). Axial ratio of the prototype antenna (L1)

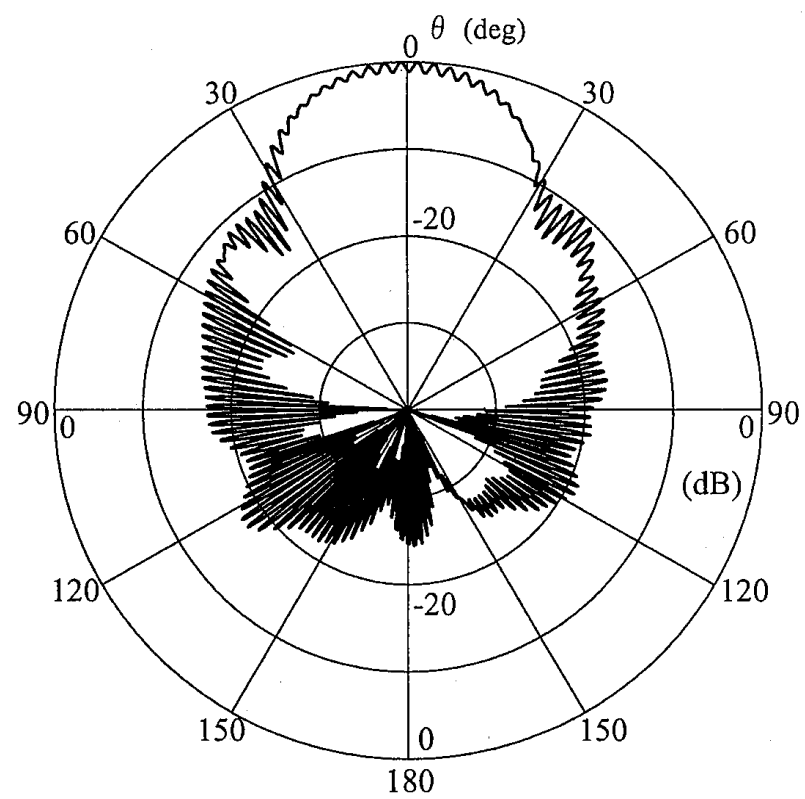

Fig. 10(b). Axial ratio of the prototype antenna (L2)

従って、ヘリカル円周を $0.98 \leqq \mathrm{C}_{\lambda} \leqq 1.12$ とする

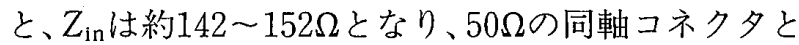
の整合をとる必要がある。文献 (2)では本アンテナと 同様に金属リムが付いた軸モードへリカルアンテナ の整合例が示されている。ここでは、給電点付近の ヘリカル素子を徐々にテーパー状にすることにより 整合をとっている。一方、今回製作したアンテナに おいては、上記の例と同様に特別な整合回路を設け ず、Fig.7に示す様に給電部分付近の板状へリカル 素子の幅を部分的に太く、不連続にすることにより 整合をとると同時に $50 \Omega$ 同軸給電管内部でも整合回 
Table 4. Specification of antenna

\begin{tabular}{ccc}
\hline & $1575.42 \mathrm{MHz}(\mathrm{L} 1)$ & $1227.6 \mathrm{MHz}(\mathrm{L} 2)$ \\
\hline Gain & $15.5 \mathrm{dBi}$ & $12.7 \mathrm{dBi}$ \\
Beam width & $26^{\circ}$ & $39^{\circ}$ \\
VSWR & 1.43 & 1.23 \\
Axial Ratio & $0.8 \mathrm{~dB}$ & $1.2 \mathrm{~dB}$ \\
\hline
\end{tabular}

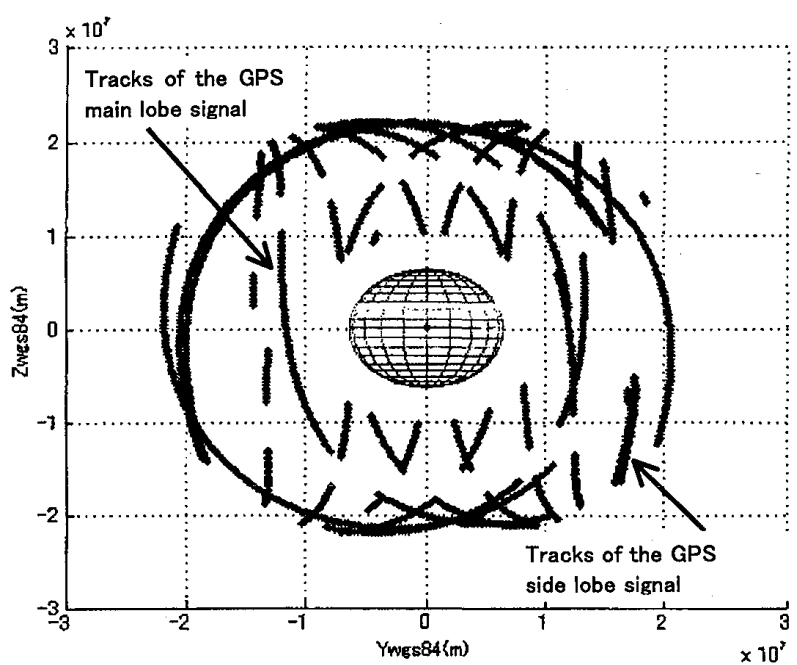

Fig. 11. GPS visibility on the geostationary orbit

路を取り付けている。その結果、実測によりFig.8に 示寸VSWRの周波数特性が得られ、1.43(L1)/ 1.23(L2)となり反射損は無視できる。

\section{2 放射特性}

放射特性の測定を行った。その結果、動作利得は $15.5 \mathrm{dBi}$ (L1)/12.7 dBi (L2)を得ることができた。 Fig. 9 に $\phi=90^{\circ}$ に扮ける指向性を前記の解析結果と 併記した。この時、ビーム幅は $26^{\circ}(\mathrm{L} 1) / 39^{\circ}(\mathrm{L} 2)$ が得 られ、解析結果より僅かにビームが鋭くなっている。 また、サイドローブは-10.5 dB(L1)/-12.0 dB(L2) となり、指向性は-20 dB以上の高いレベルにおいて、 比較的良く一致している。Fig. 10に $\phi=90^{\circ}$ における 軸比パターンを示す。ボアサイト方向の軸比は 0.8 $\mathrm{dB}(\mathrm{L} 1) / 1.2 \mathrm{~dB}(\mathrm{~L} 2)$ を得ることができた。本アンテ 十のL1/L2の 2 周波に対応した測定結果をTable 4 にまとめる。

\section{5. 静止軌道における指向性アンテナの 利用}

静止軌道上のユーザからのGPS衛星の見え方を プロットした戝をFig. 11に示す。外側の環状の軌跡 がサイドローブの受信軌跡で、内側の軌跡がメイン ローブの受信軌跡である。メインローブとサイド ローブの可視衛星数を時系列にプロットした図を Fig. 12に示す。最大可視衛星数は 9 機となった。最

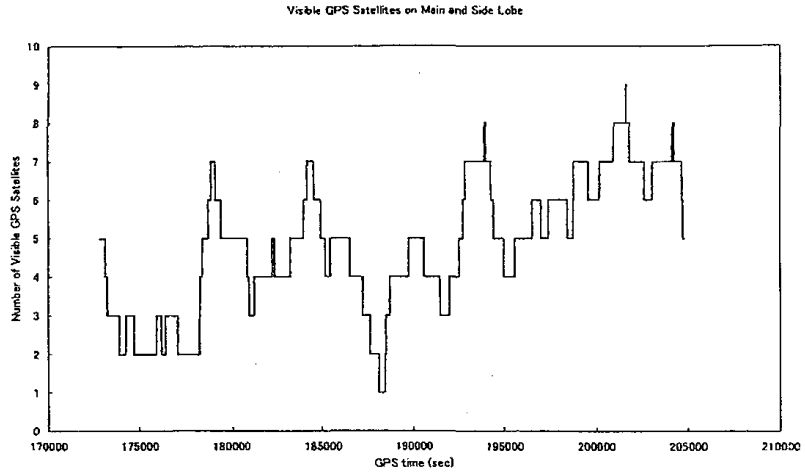

Fig. 12. Number of visible GPS satellites on the geostationary orbit

小となる場合は、1機となる時間帯も存在した。 GPS衛星が28機配備されている状態では、80\%の時 間帯で 4 機以上のGPS衛星が可視となる。ただし、 3 機以下となる時間带が 1 時間以上継続する場合が あるので、その間は高安定な周波数基準装置と、攝 動等を考慮した軌道伝播モデルで軌道決定を行う必 要がある。

\section{6. むすび}

静止衛星搭載用の高利得GPSアンテナの放射特 性解析と評価を行った。静止衛星搭載に適した特性 を得るために、モーメント法による解析により、巻 き数、リム高、ピッ千角の 3 つのパラメータについ て最適化を行った。得られたパラメー夕を用いて、 へリカルアンテナを製作し、指向性や利得を測定し 評価した。その結果、解析結果と同等の結果が得ら れた。

\section{参 考 文 献}

(1) Mehlen, C. and D. Laurichesse, "Real-time GEO Orbit Determination TOPSTAR 3000 GPS Receiver", Proc. of ION GPS-2000, pp. 1985-1994, 2000.

(2) Kraus, J.D. and Ronald J. Marhefka, "Antennas, 3rd Edition", Chapter 8 McGraw-Hill Companies, 2001.

(3) King, H.E. and J.L. Wong, "Characteristics of 1 to 8 wavelength uniform helical antennas", IEEE Trans. Antennas Propagat., Vol. AP -28, No.2, pp.291-296, March 1980.

(4) 塩川，唐沢，“軸モードへリカルアンテナの放射 特性”, 信学論 (B), Vol. J63-B, No.2, pp. 143-150（昭和55 (1980）-02）。

(5) Nakano, H., J. Yamauchi and H. Mimaki, 
"Backfire radiation from a monofilar helix with a small ground plane", IEEE Trans. Antennas Propagat., Vol. AP-36, No.10, pp. 1359-1364, Oct. 1988.

\section{質 疑 応 答}

長岡 栄(電子航法研究所)：アンテナの放射特性を 最適にしたということですが、例えば、GPS信号 のサイドローブを受信できる確率を最大にすると いうような意味でしょうか？

宮野智行：その通りです。静止軌道においてGPS衛 星が送信するGPS信号のサイドローブを受信で きるように、アンテナ利得とビーム幅の要求值を 設定しました。

織田博行（三井造船昭自研究所）：

(1)米国では指向性アンテナ等の利用による静止衛星 の軌道決定や軌道制御が実施されていますか？ま た、本研究はNASDA打上げの衛星に搭載される 計画があるのですか？
(2)衛星の自律的な軌道制御に必要となる测位精度は どの位ですか？また、本研究で得られる（期待さ れる）精度はどの程度ですか？

宮野智行(1)米国では、静止軌道でGPSを受信すると いう実験が行われていますが、実用化は現在検討 中のようです。NASDAの衛星についても、現在実 現性を検討している段階であり、具体的な搭載計 画は今のところありません。

(2)静止衛星を自動自律化するために必要な測位精度

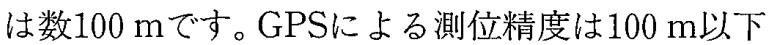
を目標精度に設定しています。

安田明生（東京商船大学）：測位精度目標が $100 \mathrm{~m}$ 以 下ということですが、DOPはどの程度ですか？

宮野智行：DOPの值は、通常50以上であり、良い時 でも数10程度です。地上にシュードライト局を設 置する方法や、高精度クロックを使用して伝播精 度を高める等の工夫をして測位精度の向上を検討 しています。 